Supporting Information

\title{
Simple Ligand Modifications with Pendent OH Groups Dramatically Impact the Activity and Selectivity of Ruthenium Catalysts for Transfer Hydrogenation: The Importance of Alkali Metals
}

Cameron M. Moore, Byongjoo Bark and Nathaniel K. Szymczak ${ }^{*}$

Department of Chemistry, University of Michigan

930 N. University, Ann Arbor, Michigan 48109 (USA)

*E-mail: nszym@umich.edu

\section{Table of Contents}

General Considerations

Synthetic Preparations

General procedure for the catalytic transfer hydrogenation of ketones

Kinetics procedures

General procedure for determining chemoselectivity

Figure S1: Kinetic data during transfer hydrogenation of 4-trifluoroacetophenone.

Figure S2: Representative kinetic data during transfer hydrogenation of acetophenone catalyzed by complex 6 acquired using Method $A$.

Figures S3: Representative kinetic data during transfer hydrogenation of acetophenone catalyzed by complex 6 acquired using Method B.

Figure S4: Effect of added ${ }^{t} \mathrm{BuOH}$ on transfer hydrogenation of acetophenone catalyzed by complex 6.

Figure S5: $162 \mathrm{MHz}{ }^{31} \mathrm{P}$ NMR spectrum of Verkade's base in ${ }^{i} \mathrm{PrOH}$.

Figure S6: Aromatic region of the $700 \mathrm{MHz}^{1} \mathrm{H}$ NMR spectrum of the hydride species 6-h in ${ }^{i} \mathrm{PrOH}$.

Figure S7: $283 \mathrm{MHz}{ }^{31} \mathrm{P}$ NMR spectrum of the hydride species 6-h in ${ }^{i} \mathrm{PrOH}$.

Figure S8: IR spectra of methanol solutions of complexes $\mathbf{6}$ and $\mathbf{9}$ in the presence of 4 equivalents of Verkade's base.

Figures S9 - S24: ${ }^{1} \mathrm{H}$ and ${ }^{31} \mathrm{P}$ NMR spectra of isolated ruthenium complexes. 


\section{General Considerations}

All liquid ketones used for transfer hydrogenation studies were either distilled under vacuum or vacuum-transferred from $\mathrm{CaH}$ and stored over $3 \AA$ A activated molecular sieves in an inert atmosphere glovebox. All other commercially-available reagents were used as received without further purification. ${ }^{i} \mathrm{PrOH}$ was distilled from $\mathrm{CaH}_{2}$ under nitrogen and stored over activated $3 \AA$ molecular sieves for $24 \mathrm{~h}$ prior to use. $\mathrm{LiB}\left(\mathrm{C}_{6} \mathrm{~F}_{5}\right)_{4} \cdot 2.5 \mathrm{Et}_{2} \mathrm{O}$ was obtained from Boulder Scientific Company and $\mathrm{NaB}\left(\mathrm{C}_{8} \mathrm{H}_{3} \mathrm{~F}_{6}\right)_{4}$ was obtained from Sigma Aldrich. Complex 1, ${ }^{1}$ dhtp, ${ }^{1} \mathrm{RuCl}_{2}\left(\mathrm{PPh}_{3}\right)_{3},{ }^{2}$ trans-RuCl(terpy) $\left(\mathrm{PPh}_{3}\right)_{2} \mathrm{PF}_{6},{ }^{3}$ complex $7^{4}$, 2,6-bis(trimethylstannyl)pyridine ${ }^{5}$ and $\mathrm{KB}\left(\mathrm{C}_{6} \mathrm{~F}_{5}\right)_{4}{ }^{6}$ were prepared as previously described. All manipulations were carried out under a purified atmosphere of nitrogen using standard Schlenk techniques or in an MBraun Lab Master 130 or Innovative Technologies Pure Lab ${ }^{\mathrm{HE}}$ GP-1 glovebox, unless otherwise stated. NMR spectra were recorded on either a Varian MR400, Varian vnmrs 500 or Varian vnmrs 700 spectrometer and are referenced to residual solvent peaks for spectra collected in deuterated samples. For samples collected in ${ }^{i} \mathrm{PrOH}$, added trimethyl(phenyl)silane was referenced to $0.1 \mathrm{ppm}$. IR spectra were collected using a Nicolet iS10 spectrometer equipped with a diamond attenuated total reflectance (ATR) accessory. GC/MS analyses were performed using a Shimadzu QP2010 GC/MS, ESI-MS analyses were performed using a Micromass LCT TOF spectrometer and HRMS analyses were performed using an Agilent Q-TOF HPLC spectrometer. Elemental analysis was performed by Midwest Microlabs, LLC, Indianapolis, IN.

\section{Synthetic Considerations}

\section{$\operatorname{CsB}\left(C_{6} F_{5}\right)_{4}$}

This compound was prepared in an analogous fashion to $\mathrm{KB}\left(\mathrm{C}_{6} \mathrm{~F}_{5}\right)_{4} \cdot{ }^{6} \mathrm{~A}$ filtered solution of $\mathrm{CsF}(0.3213 \mathrm{~g}$; $2.115 \mathrm{mmol}$ dissolved in $5 \mathrm{~mL}$ methanol) was added dropwise to a stirring solution of $\mathrm{LiB}\left(\mathrm{C}_{6} \mathrm{~F}_{5}\right)_{4} \cdot 2.5 \mathrm{Et}_{2} \mathrm{O}$ $(1.0079 \mathrm{~g} ; 1.157 \mathrm{mmol})$ in methanol $(1 \mathrm{~mL})$. The reaction mixture rapidly became turbid and was stirred for an additional $15 \mathrm{~min}$, then concentrated to a milky residue. The residue was extracted with diethyl ether (ca. $10 \mathrm{~mL}$ ) and filtered. The filtrate was concentrated to a white solid, which was subsequently dried at $80{ }^{\circ} \mathrm{C}$ (0.1 torr) for $18 \mathrm{~h}$ to give the title compound as a white powder $(0.5412 \mathrm{~g} ; 58 \%) .{ }^{19} \mathrm{~F} \mathrm{NMR}$ $376 \mathrm{MHz}$ (acetone- $\left.d_{6}\right), \delta$ (ppm): -133.08 (br s, 8F), -164.43 (t, $\left.J=19,4 \mathrm{~F}\right),-168.35(\mathrm{~d}, J=19,8 \mathrm{~F}) .{ }^{11} \mathrm{~B}$ NMR $128 \mathrm{MHz}$ (acetone- $d_{6}$ ), $\delta$ (ppm): -16.67 (br s). ESI-MS (acetone, $\left.\mathrm{ES}^{+}\right): \mathrm{m} / \mathrm{z}=132.9\left(\mathrm{Cs}^{+}\right.$). ESI-MS (acetone, $\left.E^{-}\right): m / z=678.8\left(B\left(C_{6} F_{5}\right)_{4}^{-}\right)$.

\section{4,4'-dichloro terpyridine}

In a Schlenk tube in the open air, 2,6-bis(trimethylstannyl)pyridine (1.877 g; $4.64 \mathrm{mmol}$ ), 2-bromo,4chloropyridine $(2.247 \mathrm{~g} ; 11.68 \mathrm{mmol}$ ) and toluene $(50 \mathrm{~mL})$ were combined. The tube was sealed and evacuated by three freeze-pump-thaw cycles and refilled with nitrogen. Under a nitrogen atmosphere, $\mathrm{Pd}\left(\mathrm{PPh}_{3}\right)_{4}(0.394 \mathrm{~g} ; 0.34 \mathrm{mmol}$, dissolved in ca. $40 \mathrm{~mL}$ toluene) was added to the solution. The tube was sealed and placed in a $110^{\circ} \mathrm{C}$ oil bath and stirred. After three days, the mixture was allowed to cool to ambient temperature and concentrated to dryness on a rotary evaporator. The dark residue was then extracted with boiling ethyl acetate and filtered. Upon standing, crystals of the product emerged from the filtrate and were collected by filtration, washed with a minimal amount of ethyl acetate then 
hexanes. An additional crop of crystalline product could be obtained by cooling the above filtrate overnight at $-25^{\circ} \mathrm{C}$. The obtained material was combined and dried to provide the title compound as a white powder (0.857 g; 61\%). ${ }^{1} \mathrm{H}$ NMR $400 \mathrm{MHz}\left(\mathrm{CDCl}_{3}\right), \delta(\mathrm{ppm}): 8.60(\mathrm{~m}, 4 \mathrm{H}), 8.47(\mathrm{~d}, J=8,2 \mathrm{H}), 7.98(\mathrm{t}$, $J=7.6 \mathrm{~Hz}, 1 \mathrm{H}$ ), $7.36\left(\mathrm{dd}, J=2\right.$ and $5.2,2 \mathrm{H}$ ). The ${ }^{1} \mathrm{H}$ NMR characterization data is consistent with the previous report of this compound. ${ }^{7}$

\section{4,4'-dihydroxy terpyridine}

In small vial in the open atmosphere, 4,4'-dichloro terpyridine (152.2 mg; $0.504 \mathrm{mmol}), \mathrm{NaOH}(110.5$ $\mathrm{mg} ; 2.76 \mathrm{mmol})$ and $\mathrm{dmso}(3 \mathrm{~mL})$ were combined. The vial was sealed with a Teflon-lined cap and the mixture was heated to $120^{\circ} \mathrm{C}$ and stirred. After 17 hours, the brown/red reaction mixture was cooled to ambient temperature and $\mathrm{H}_{2} \mathrm{O}(3 \mathrm{~mL})$ was added. The mixture was then filtered yielding an orange filtrate. Formic acid was added dropwise to the filtrate until a $\mathrm{pH}$ of 4 was reached producing a milky suspension. The suspension was cooled in a $5{ }^{\circ} \mathrm{C}$ refrigerator and a beige solid settled from the mixture. The solid was collected on a sintered glass frit and washed with $\mathrm{H}_{2} \mathrm{O}(2 \times 5 \mathrm{~mL})$, copious amounts of acetone and then dried to provide the title compound as a beige powder (107.9 $\mathrm{mg} ; 81 \%)$. The compound was used without further purification. ${ }^{1} \mathrm{H} N \mathrm{NMR} 500 \mathrm{MHz}\left(\mathrm{CD}_{3} \mathrm{OD}\right), \delta(\mathrm{ppm}): 8.28(\mathrm{~m}, 2 \mathrm{H}), 8.21$ $(\mathrm{m}, 1 \mathrm{H}), 8.02(\mathrm{~d}, J=7.0,2 \mathrm{H}), 7.30(\mathrm{~d}, J=2.5,2 \mathrm{H}), 6.61(\mathrm{dd}, J=2.5$ and $7.5,2 \mathrm{H}) .{ }^{13} \mathrm{C} \mathrm{NMR} 126 \mathrm{MHz}$ $\left(\mathrm{CD}_{3} \mathrm{OD}\right), \delta(\mathrm{ppm}): 181.7,150.3,147.3,141.3,140.7,123.5,117.8,115.1$. ATR-IR $\left(\mathrm{cm}^{-1}\right): 3190,3116$, $3078,1628,1524,1464,997,818$. HRMS (ESI): $\mathrm{m} / \mathrm{z}=266.0925\left([\mathrm{M}+\mathrm{H}]^{+}\right.$, predicted: 266.0924).

\section{$\left[\mathrm{Ru}\left(\text { dhtp" }^{\prime}\right)\left(\mathrm{PPh}_{3}\right)\right]_{2} \mathrm{OH}_{2}(1-\mathrm{d})$}

Dichloromethane $(15 \mathrm{~mL}$ ) was added to solid 2 (54.1 $\mathrm{mg} ; 0.0773 \mathrm{mmol}$ ) and $\mathrm{NaOH}$ (32.1 mg; 0.803 $\mathrm{mmol}$ ) and the resulting mixture was stirred. After $24 \mathrm{~h}$, the purple mixture was dried over $\mathrm{Na}_{2} \mathrm{SO}_{4}$, filtered and concentrated to a minimal volume. Addition of hexanes to the purple solution produced a precipitate, which was collected on a sintered glass, washed with copious amounts of hexanes and dried to give the title compound as a deep purple powder (29.2 mg; 59\%). Crystals suitable for an X-ray diffraction experiment were grown from vapor diffusion of pentane into a benzene solution of 1-d. ${ }^{1} \mathrm{H}$ NMR, $400 \mathrm{MHz}\left(\mathrm{C}_{6} \mathrm{D}_{6}\right), \delta(\mathrm{ppm}): 16.00(\mathrm{~s}, 2 \mathrm{H}), 7.60-7.63(\mathrm{~m}, 11 \mathrm{H}), 6.88-6.93(\mathrm{~m}, 21 \mathrm{H}), 6.77(\mathrm{~d}, J=7.6$, $2 \mathrm{H}), 6.55(\mathrm{t}, J=8.0,2 \mathrm{H}), 6.45-6.51(\mathrm{~m}, 6 \mathrm{H}), 6.37(\mathrm{t}, J=7.6,2 \mathrm{H}), 6.05(\mathrm{~d}, J=7.2,2 \mathrm{H}), 5.95(\mathrm{~d}, J=8.4,2 \mathrm{H})$. ${ }^{31} \mathrm{P}\left\{{ }^{1} \mathrm{H}\right\} \mathrm{NMR}, 162 \mathrm{MHz}\left(\mathrm{C}_{6} \mathrm{D}_{6}\right), \delta(\mathrm{ppm}): 58.94(\mathrm{~s}, \mathrm{PPh}) . \operatorname{ATR}-\mathrm{IR}\left(\mathrm{cm}^{-1}\right): 3049\left(\mathrm{OH}_{2}\right), 1597,1474,1414$, $1381,1227,1090,1007,779,741,694$. HRMS (ESI): $\mathrm{m} / \mathrm{z}=1272.1473$ ([M-2H $]^{+}$, predicted: 1272.1259).

\section{cis-RuCl ${ }_{2}(\mathrm{dhtp}) \mathrm{PPh}_{3}(2)$}

Toluene (ca. $150 \mathrm{~mL}$ ) was added to a mixture of dhtp $(0.300 \mathrm{~g} ; 1.13 \mathrm{mmol})$ and $\mathrm{RuCl}_{2}\left(\mathrm{PPh}_{3}\right)_{3}(1.139 \mathrm{~g}$; $1.19 \mathrm{mmol}$ ). The mixture was stirred and heated to a vigorous reflux for $24 \mathrm{~h}$, during which time a magenta precipitate emerged. The mixture was allowed to cool to room temperature and the precipitate was collected on a sintered glass frit in the open air. The solid was washed with toluene until the eluent was colorless, then washed with copious amounts of hexanes and dried to give to the title compound as a dark maroon powder ( $0.735 \mathrm{~g}$; $93 \%$ yield). Crystals suitable for an X-ray diffraction experiment were grown from vapor diffusion of diethyl ether into a dimethylformamide solution of $2 .{ }^{1} \mathrm{H}$ 
NMR, $400 \mathrm{MHz}\left(\mathrm{dmso}-d_{6}\right), \delta(\mathrm{ppm}): 10.71(\mathrm{~s}, 2 \mathrm{H}), 8.05(\mathrm{~d}, J=8.0,2 \mathrm{H}), 7.85(\mathrm{~m}, 3 \mathrm{H}), 7.69-7.77(\mathrm{~m}, 2 \mathrm{H})$, $7.29(\mathrm{t}, J=8.0,6 \mathrm{H}), 7.13(\mathrm{t}, J=6.0,6 \mathrm{H}), 6.99(\mathrm{dd}, J=2.8$ and $6.0,2 \mathrm{H}), 6.88(\mathrm{t}, J=8.8,6 \mathrm{H}) .{ }^{31} \mathrm{P}\left\{{ }^{1} \mathrm{H}\right\} \mathrm{NMR}$, $162 \mathrm{MHz}\left(\mathrm{dmso}-d_{6}\right), \delta(\mathrm{ppm}): 45.92\left(\mathrm{~s}, \mathrm{PPh}_{3}\right)$. ATR-IR $\left(\mathrm{cm}^{-1}\right): 3054(\mathrm{OH}), 1614,1569,1481,1435,1391$, $1215,1158,1089,999,791,760,739,694$. HRMS (ESI): $\mathrm{m} / \mathrm{z}=664.0503$ ([M-Cl] ${ }^{+}$, predicted: 664.0498).

\section{trans-RuCl(dhtp)( $\left.\mathrm{PMe}_{3}\right)_{2} \mathrm{PF}_{6}(3)$}

Compound 1 ( $58.4 \mathrm{mg} ; 0.0545 \mathrm{mmol}$ ) was suspended in benzene $(c a .10 \mathrm{~mL}$ ) in a scintillation vial and trimethylphosphine ( $34 \mu \mathrm{L} ; 0.33 \mathrm{mmol}$ ) was added. The vial was sealed with a Teflon-lined cap and heated to $85^{\circ} \mathrm{C}$ with vigorous stirring for $1.5 \mathrm{~h}$. The reaction was then cooled to ambient temperature and pentane $(c a .10 \mathrm{~mL})$ was added to produce a precipitate. The precipitate was collected on a sintered glass frit, washed with copious amounts of pentane and then dried to give the title compound as a bright orange powder ( $32.8 \mathrm{mg} ; 86 \%$ yield). Crystals of 4.3 suitable for $\mathrm{X}$-ray diffraction were grown from vapor diffusion of diethyl ether into a dichloromethane solution of 4.3 at $5{ }^{\circ} \mathrm{C}$. ${ }^{1} \mathrm{H} \mathrm{NMR}, 400 \mathrm{MHz}$ $\left(\mathrm{CD}_{2} \mathrm{Cl}_{2}\right), \delta(\mathrm{ppm}): 10.14(\mathrm{~s}, 2 \mathrm{H}), 8.17(\mathrm{~d}, J=8.0,2 \mathrm{H}), 8.03(\mathrm{t}, J=8.0,1 \mathrm{H}), 7.97(\mathrm{t}, J=8.0,2 \mathrm{H}), 7.87(\mathrm{~d}, J=$ 7.6, $2 \mathrm{H}), 7.10(\mathrm{~d}, J=8.0,2 \mathrm{H}), 0.78(\mathrm{t}, J=3.2,18 \mathrm{H}) .{ }^{31} \mathrm{P}\left\{{ }^{1} \mathrm{H}\right\} \mathrm{NMR}, 162 \mathrm{MHz}\left(\mathrm{CD}_{2} \mathrm{Cl}_{2}\right), \delta(\mathrm{ppm}):-5.22(\mathrm{~s}$, $\mathrm{PMe}_{3}$ ), -144.48 (sep., $J=709, \mathrm{PF}_{6}{ }^{-}$). ATR-IR (cm-1): 3074 (OH), 1616, 1568, 1490, 1425, 1387, 1285, 1205, 1166, $835\left(\mathrm{PF}_{6}{ }^{-}\right), 791,732,667$. Anal. Calculated (Found): C, 36.09 (35.99); H, 4.18 (4.03); N, 6.01 (5.92).

\section{trans-RuCl(dhtp)( $\left.\mathrm{PPh}_{3}\right)_{2} \mathrm{PF}_{6}(4)$}

Compound 1 (65.8 mg; $0.0614 \mathrm{mmol}$ ) was suspended in benzene (ca. $10 \mathrm{~mL}$ ) in a scintillation vial and triphenylphosphite ( $97 \mu \mathrm{L} ; 0.37 \mathrm{mmol}$ ) was added. The vial was sealed with a Teflon-lined cap and heated to $85^{\circ} \mathrm{C}$ with vigorous stirring for $1 \mathrm{~h}$. The reaction was then cooled to ambient temperature and pentane $(c a .10 \mathrm{~mL}$ ) was added to produce a precipitate. The precipitate was collected on a sintered glass frit, washed with copious amounts of pentane and then dried to give the title compound as a bright yellow powder (60.8 mg; 85\% yield). ${ }^{1} \mathrm{H} N \mathrm{NMR}, 400 \mathrm{MHz}\left(\mathrm{CD}_{2} \mathrm{Cl}_{2}\right), \delta(\mathrm{ppm}): 9.88(\mathrm{~s}, 2 \mathrm{H}), 7.92(\mathrm{~s}, 3 \mathrm{H})$, $7.80(\mathrm{t}, J=8.0,2 \mathrm{H}), 7.70(\mathrm{~d}, J=7.2,2 \mathrm{H}), 7.05(\mathrm{~m}, 18 \mathrm{H}), 6.66(\mathrm{~d}, J=8.4,2 \mathrm{H}), 6.55(\mathrm{~d}, J=8.0,12 \mathrm{H}) .{ }^{31} \mathrm{P}\left\{{ }^{1} \mathrm{H}\right\}$ NMR, $162 \mathrm{MHz}\left(\mathrm{CD}_{2} \mathrm{Cl}_{2}\right), \delta(\mathrm{ppm}): 101.57$ (s, $\left.\mathrm{P}\left\{\mathrm{OPh}_{3}\right\}\right),-144.29$ (sep., $\left.J=709, \mathrm{PF}_{6}{ }^{-}\right)$. ATR-IR (cm-1): 3112 $(\mathrm{OH}), 1586,1484,1403,1208,1163,898,834\left(\mathrm{PF}_{6}{ }^{-}\right), 790,688$. Anal. Calculated (Found): C, 52.48 (52.35); H, 3.54 (3.48); N, 3.60 (3.54).

\section{RuCl(4-methoxypyridine)dhtp(PPh $) \mathrm{PF}_{6}(5)$}

Dichloromethane $(10 \mathrm{~mL})$ was added to a mixture of $2(56.9 \mathrm{mg} ; 0.0813 \mathrm{mmol})$ and $\mathrm{TIPF}_{6}$ (31.2 $\mathrm{mg}$; $0.0893 \mathrm{mmol}$ ), followed by 4-methoxypyridine ( $25 \mu \mathrm{L} ; 0.25 \mathrm{mmol}$ ). The mixture was stirred for $2 \mathrm{~h}$ to give an orange suspension. The mixture was filtered and hexane $(50 \mathrm{~mL})$ was added to the orange filtrate causing an orange oil to separate. The supernatant was decanted from the oil, which was subsequently triturated with diethyl ether to give an orange solid. The orange solid was collected on a sintered glass frit, washed with copious amounts of diethyl ether and dried to give the title compound as an orange powder (65.2 mg; 73\% yield). Crystals of 5 with a $\mathrm{BPh}_{4}{ }^{-}$counteranion suitable for $\mathrm{X}$-ray diffraction were grown by reacting 5 with excess $\mathrm{NaBPh}_{4}$ in dichloromethane and allowing diethyl ether to diffuse into the resulting solution. ${ }^{1} \mathrm{H} N M R, 400 \mathrm{MHz}\left(\mathrm{CD}_{2} \mathrm{Cl}_{2}\right), \delta(\mathrm{ppm}): 10.57(\mathrm{~s}, 2 \mathrm{H}), 7.75-7.80(\mathrm{~m}$, 
$5 \mathrm{H}), 7.62(\mathrm{~d}, J=5.2,2 \mathrm{H}), 7.54(\mathrm{~d}, J=7.6,2 \mathrm{H}), 7.32(\mathrm{t}, J=7.2,3 \mathrm{H}), 7.14(\mathrm{t}, J=6.4,6 \mathrm{H}), 7.01(\mathrm{t}, J=9.2,6 \mathrm{H})$, $6.90(\mathrm{~d}, J=8.4,2 \mathrm{H}), 6.62(\mathrm{~d}, J=6.8,2 \mathrm{H}), 3.71(\mathrm{~s}, 3 \mathrm{H}) .{ }^{31} \mathrm{P}\left\{{ }^{1} \mathrm{H}\right\} \mathrm{NMR}, 162 \mathrm{MHz}\left(\mathrm{CD}_{2} \mathrm{Cl}_{2}\right), \delta(\mathrm{ppm}): 40.31(\mathrm{~s}$, $\mathrm{PPh}_{3}$ ), -144.42 (sep., $J=710, \mathrm{PF}_{6}{ }^{-}$). ATR-IR (cm $\left.{ }^{-1}\right): 3072(\mathrm{OH}), 1614,1571,1490,1392,1299,1212,1164$, 1032, $838\left(\mathrm{PF}_{6}^{-}\right), 749,696,658 . \mathrm{HRMS}(\mathrm{ESI}): \mathrm{m} / \mathrm{z}=773.1021\left(\left[\mathrm{M}-\mathrm{PF}_{6}\right]^{+}\right.$, predicted: 773.1017$)$.

\section{$\operatorname{RuCl}(\mathrm{CO}) \operatorname{dhtp}\left(\mathrm{PPh}_{3}\right) \mathrm{PF}_{6}(6)$}

Dichloromethane $(50 \mathrm{~mL})$ was added to a mixture of $2(0.250 \mathrm{~g} ; 0.357 \mathrm{mmol})$ and TIPF $_{6}(0.132 \mathrm{~g} ; 0.378$ $\mathrm{mmol}$ ) in a Fisher-Porter tube in the open atmosphere. The tube was purged with CO multiple times, then charged to a pressure of $50 \mathrm{psi}$. The resulting mixture was stirred for 22 hours, during which time the mixture turned from magenta to orange. The mixture was then filtered through Celite in the open atmosphere into a stirring solution of pentane (ca. $200 \mathrm{~mL}$ ). The resulting yellow precipitate was collected on a sintered glass frit, washed with copious amounts of pentane and then dried to give the title compound as a bright yellow powder (0.261 g; 87\%). ${ }^{1} \mathrm{H} \mathrm{NMR}, 400 \mathrm{MHz}\left(\mathrm{CD}_{2} \mathrm{Cl}_{2}\right), \delta$ (ppm): 10.08 (s, $2 \mathrm{H}), 8.05(\mathrm{t}, J=8.4,1 \mathrm{H}), 7.87-7.92(\mathrm{~m}, 4 \mathrm{H}), 7.62(\mathrm{~d}, J=7.6,2 \mathrm{H}), 7.40(\mathrm{t}, J=7.6,3 \mathrm{H}), 7.21(\mathrm{dt}, J=1.6$ and 8.0,6H), $7.03(\mathrm{~d}, J=8.4,2 \mathrm{H}), 6.98(\mathrm{t}, J=9.2,6 \mathrm{H}) .{ }^{31} \mathrm{P}\left\{{ }^{1} \mathrm{H}\right\} \mathrm{NMR}, 162 \mathrm{MHz}\left(\mathrm{CD}_{2} \mathrm{Cl}\right.$ ) $, \delta(\mathrm{ppm}): 16.97(\mathrm{~s}$, $\mathrm{PPh}_{3}$ ), -144.40 (sep., $J=709, \mathrm{PF}_{6}^{-}$). ATR-IR (cm $\left.{ }^{-1}\right): 3097(\mathrm{OH}), 2046$ (CO), 1620, 1573, 1495, 1404, 1286, 1212, 1167, $851\left(\mathrm{PF}_{6}{ }^{-}\right), 794,750,698$. Anal. Calculated (Found): C, 48.79 (48.74); H, 3.13 (2.99); N, 5.02 (4.97).

\section{$\left[\operatorname{RuH}\left(\right.\right.$ dhtp") $\left.\mathrm{CO}\left(\mathrm{PPh}_{3}\right)\right]\left[\mathrm{H}-\mathrm{PN}\left(\mathrm{CH}_{2} \mathrm{~N}\left\{\mathrm{CH}\left(\mathrm{CH}_{3}\right)_{2}\right\}\right)_{3}\right](6-\mathrm{h})$}

A solution of Verkade's base in ' $\mathrm{PrOH}(0.48 \mathrm{~mL}$ of $0.1 \mathrm{M}$ solution; $0.0048 \mathrm{mmol}$ ) was added to solid 6 (2.0 $\mathrm{mg} ; 0.0024 \mathrm{mmol}$ ), followed by trimethyl(phenyl)silane ( $5 \mu \mathrm{L} ; 0.029 \mathrm{mmol}$, used as internal standard) in a small vial and stirred for $20 \mathrm{~min}$. The bright red/orange solution was then transferred to re-sealable NMR tube. ${ }^{1} \mathrm{H}$ and ${ }^{31} \mathrm{P}$ NMR spectroscopy revealed quantitative conversion to 6-h. ${ }^{1} \mathrm{H}$ NMR, $700 \mathrm{MHz}$ ('PrOH), $\delta(\mathrm{ppm}): 7.51(\mathrm{t}, J=7.0,1 \mathrm{H}), 7.38(\mathrm{~d}, J=7.7,2 \mathrm{H}), 7.04(\mathrm{t}, J=9.1,6 \mathrm{H}), 6.97(\mathrm{t}, J=7.7,3 \mathrm{H}), 6.88(\mathrm{t}$, $J=7.7,6 \mathrm{H}), 6.80(\mathrm{t}, J=7.7,2 \mathrm{H}), 6.46(\mathrm{~d}, J=7.0,2 \mathrm{H}), 6.12(\mathrm{~d}, J=8.4,2 \mathrm{H}),-8.91(\mathrm{~d}, J=106.4,1 \mathrm{H}) .{ }^{31} \mathrm{P}$ $\mathrm{NMR}, 283 \mathrm{MHz}$ ('PrOH), $\delta(\mathrm{ppm}): 33.52\left(\mathrm{~d}, J=105, \mathrm{PPh}_{3}\right),-11.73\left(\mathrm{~d}, J=496, \mathrm{H}-\mathrm{PN}\left(\mathrm{CH}_{2} \mathrm{~N}\left\{\mathrm{CH}\left(\mathrm{CH}_{3}\right)_{2}\right\}\right)_{3}{ }^{+}\right)$

\section{trans-RuCl(4-dhtp)(PPh $)_{2} \mathrm{PF}_{6}(8)$}

Deoxygenated methanol $(30 \mathrm{~mL}$ ) was added to the solids 4-dhtp (45.8 mg; $0.173 \mathrm{mmol})$ and $\mathrm{RuCl}_{2}\left(\mathrm{PPh}_{3}\right)_{3}$ (175.5 mg; $0.183 \mathrm{mmol}$ ) under a nitrogen atmosphere. The mixture was heated to $50{ }^{\circ} \mathrm{C}$ and stirred. After 24 hours, the reaction was allowed to cool to ambient temperature and solid TIPF $_{6}(64.7 \mathrm{mg} ; 0.185$ $\mathrm{mmol}$ ) was added and the mixture was stirred for a further hour under nitrogen. The orange mixture was then filtered through Celite in the open atmosphere and diethyl ether $(20 \mathrm{~mL})$ and hexanes (200 $\mathrm{mL}$ ) were added to the filtrate. The resulting orange precipitate was collected on a sintered glass frit in the open atmosphere, washed with copious amounts of diethyl ether and dried to give the title compound as an orange powder (145.9 mg; 79\%). ${ }^{1} \mathrm{H} \mathrm{NMR}, 400 \mathrm{MHz}\left(\mathrm{CD}_{3} \mathrm{OD}\right), \delta(\mathrm{ppm}): 8.61$ (d, $J=6.4$, $2 \mathrm{H})$, 7.39-7.48 (m, 3H), 7.17-7.27 (m, 20H), $7.09(\mathrm{t}, J=7.6,12 \mathrm{H}), 6.21(\mathrm{dd}, J=2.8$ and $6.4,2 \mathrm{H}) .{ }^{31} \mathrm{P}\left\{{ }^{1} \mathrm{H}\right\}$ $\mathrm{NMR}, 162 \mathrm{MHz}\left(\mathrm{CD}_{3} \mathrm{OD}\right), \delta$ (ppm): 21.92 (s, $\left.\mathrm{PPh}_{3}\right),-144.62$ (sep., J = 710, $\left.\mathrm{PF}_{6}{ }^{-}\right) . \operatorname{ATR}-\mathrm{IR}\left(\mathrm{cm}^{-1}\right): 3059(\mathrm{OH})$, 
1618, 1458, 1221, 1090, $844\left(\mathrm{PF}_{6}^{-}\right), 741,695 . \mathrm{HRMS}(\mathrm{ESI}): \mathrm{m} / \mathrm{z}=926.1409\left(\left[\mathrm{M}-\mathrm{PF}_{6}\right]^{+}\right.$, predicted:

926.1401).

\section{$\operatorname{RuCl}(\mathrm{CO}) 4-\mathrm{dhtp}\left(\mathrm{PPh}_{3}\right) \mathrm{PF}_{6}(9)$}

Complex 8 (50.6 mg; $0.047 \mathrm{mmol}$ ) was suspended in dichloromethane $(20 \mathrm{~mL})$ in a Fisher -Porter tube in the open atmosphere. The tube was purged with $\mathrm{CO}$ then pressurized to $60 \mathrm{psi}$ and stirred. After 24 hours, hexanes $(20 \mathrm{~mL})$ was added to the mixture in the open air and the resulting precipitate was collected on a sintered glass frit, washed with copious amounts of hexanes and diethyl ether and then dried to provide the title compound as a pale orange powder (30.3 mg; 72\%). ${ }^{1} \mathrm{H} \mathrm{NMR}, 500 \mathrm{MHz}$ $\left(\mathrm{CD}_{3} \mathrm{OD}\right), \delta(\mathrm{ppm}): 8.66(\mathrm{~d}, J=6.5,2 \mathrm{H}), 8.03(\mathrm{~d}, J=8.0,2 \mathrm{H}), 7.96(\mathrm{t}, J=7.5,1 \mathrm{H}), 7.63(\mathrm{~d}, J=2.0,2 \mathrm{H}), 7.35$ $(\mathrm{t}, J=7.0,3 \mathrm{H}), 7.26(\mathrm{t}, J=8.5,6 \mathrm{H}), 7.19-7.22(\mathrm{~m}, 6 \mathrm{H}), 6.99(\mathrm{dd}, J=2.0$ and $6.0,2 \mathrm{H}) .{ }^{31} \mathrm{P}\left\{{ }^{1} \mathrm{H}\right\} \mathrm{NMR}, 202$ $\mathrm{MHz}\left(\mathrm{CD}_{3} \mathrm{OD}\right), \delta(\mathrm{ppm}): 13.19\left(\mathrm{~s}, \mathrm{PPh}_{3}\right),-144.61$ (sep., $\left.J=707, \mathrm{PF}_{6}{ }^{-}\right)$. ATR-IR $\left(\mathrm{cm}^{-1}\right): 3428(\mathrm{OH}), 3233(\mathrm{OH})$, 2020 (CO), 1619, 1567, 1453, 1335, 1213, 1092, 1019, $847\left(\mathrm{PF}_{6}{ }^{-}\right), 742,696 . \mathrm{HRMS}$ (ESI): $\mathrm{m} / \mathrm{z}=664.0495$ ([M-CO-PF $]^{+}$, predicted: 664.0489).

\section{General procedure for the catalytic transfer hydrogenation of ketones}

These experiments were typically run in NMR tubes as follows:

In a nitrogen-filled glovebox, a catalyst stock solution of ruthenium complex and base was prepared by adding ${ }^{i} \mathrm{PrOH}(10 \mathrm{~mL})$ to ruthenium complex $(0.006 \mathrm{mmol})$ and base (either $\mathrm{KO}^{t} \mathrm{Bu}$ or Verkade's base, $0.12 \mathrm{mmol}$ ), to afford a homogeneous solution. An aliquot of this solution ( $420 \mu \mathrm{L} ; 0.00025 \mathrm{mmol}$ ruthenium and $0.0050 \mathrm{mmol}$ of base) was added to an NMR tube, followed by the ketone substrate $(0.05 \mathrm{mmol})$, trimethyl(phenyl)silane $(5.0 \mu \mathrm{L} ; 0.029 \mathrm{mmol})$ as an internal standard and any additives for experiments involving cation effects (i.e. $\mathrm{KB}\left(\mathrm{C}_{6} \mathrm{~F}_{5}\right)_{4} ; 0.0050 \mathrm{mmol}$ ). The solution was diluted with ${ }^{i} \mathrm{PrOH}$ to reach a final volume of $0.500 \mathrm{~mL}$. The tube was sealed inside the glovebox and protected with 3-5 layers of electrical tape. The tube was removed from the glovebox and an initial ${ }^{1} \mathrm{H}$ NMR spectrum was recorded, then the tube was placed in a pre-heated oil bath at $80{ }^{\circ} \mathrm{C} .{ }^{1} \mathrm{H}$ NMR spectra were recorded at the specified time intervals and the amount of product formed was calculated using the trimethyl(phenyl)silane resonance as an integration standard.

\section{Kinetics procedures}

\section{Method A:}

In a small vial in a nitrogen-filled glovebox, acetophenone (29-102 $\mu \mathrm{L} ; 0.25-0.875 \mathrm{mmol})$, trimethyl(phenyl)silane ( $10 \mu \mathrm{L} ; 0.058 \mathrm{mmol})$ and complex $6(200 \mu \mathrm{L}$ of a $0.012 \mathrm{M}$ solution in acetone; $0.0024 \mathrm{mmol}$ ) were combined. Note that complex 6 is not soluble in ${ }^{i} \mathrm{PrOH}$ in the absence of base and a stock solution using acetone was required. Then $\mathrm{KO}^{t} \mathrm{Bu}\left(50-2500 \mu \mathrm{L}\right.$ of a $0.1 \mathrm{M}$ solution in ${ }^{i} \mathrm{PrOH} ; 0.005$ $-0.25 \mathrm{mmol}$ ) was added. The solution was diluted with an appropriate amount of ${ }^{i} \mathrm{PrOH}$ to reach a final volume of $5 \mathrm{~mL}$. The vial was sealed with a Teflon-lined cap and heated at $80^{\circ} \mathrm{C}$. Aliquots $(0.5 \mathrm{~mL})$ were removed for NMR spectroscopy in 10 minute intervals to determine the concentration of acetophenone at a given time point using the trimethyl(phenyl)silane resonance as an internal standard. For each 
condition, this experiment was repeated in triplicate to establish error. Method A was used to determine acetophenone dependence, $\mathrm{KO}^{t} \mathrm{Bu}$ dependence and for the Hammett studies. Note for the base dependence studies, the background rate of the base catalyzed Meerwein-Ponndorf-Verley reduction of acetophenone was subtracted from the observed profile.

Method B:

The tubes were prepared as noted above and then inserted into a pre-warmed NMR spectrometer at the desired temperature $\left(50,60,70\right.$ or $\left.80^{\circ} \mathrm{C}\right)$. Arrayed spectra were acquired every minute for the first 10 minutes of the reaction upon inserting the sample into the spectrometer. Baseline corrections for the arrayed spectra were made using the vnmrj baseline correction command ' $\mathrm{fbc}^{\prime}$ ' and the acetone resonance was integrated against the internal trimethyl(phenyl)silane resonance to determine the concentration of acetone at a given time point. For each condition, this experiment was repeated in triplicate to establish error. Method B was used to perform the Eyring analysis, to measure catalysis using Verkade's base and for cation effect experiments.

\section{General procedure for determining chemoselectivity}

The general procedure outlined above for the catalytic transfer hydrogenation of ketones was used, except the reactions were performed in a 1 dram vial with stirbar in a nitrogen filled glovebox. Aliquots $(10 \mu \mathrm{L})$ were taken from the reaction and diluted with chloroform $(1.0 \mathrm{~mL})$, then analyzed by $\mathrm{GC} / \mathrm{MS}$ using a Shimadzu QP-2010 GC/MS equipped with a $30 \mathrm{~m}$ long DB-5 column with a $0.25 \mathrm{~mm}$ inner diameter. The heating scheme used was as follows: $25^{\circ} \mathrm{C}$ hold for $15 \mathrm{~min}$, ramp $20^{\circ} \mathrm{C} / \mathrm{min}$ until $270{ }^{\circ} \mathrm{C}$, and hold $270{ }^{\circ} \mathrm{C}$ for $5 \mathrm{~min}$.

\section{X-ray crystallography}

Crystals were mounted on a Rigaku AFC10K Saturn 944+ CCD-based X-ray diffractometer equipped with a low temperature device and Micromax-007HF Cu-target micro-focus rotating anode $(\lambda=1.54187 \mathrm{~A})$ operated at $1.2 \mathrm{~kW}$ power $(40 \mathrm{kV}, 30 \mathrm{~mA})$. The $\mathrm{X}$-ray intensities were measured at $85(2) \mathrm{K}$ with the detector placed at a distance $42.00 \mathrm{~mm}$ from the crystal. Analysis of the data showed negligible decay during data collection; the data were processed with CrystalClear $2.0^{8}$ and corrected for absorption. The structures were solved and refined with the Bruker SHELXTL software package. ${ }^{9}$ All non-hydrogen atoms were refined anisotropically with the hydrogen atoms placed in a mix of idealized and refined positions. Please see the accompanying .cif files for more information. 


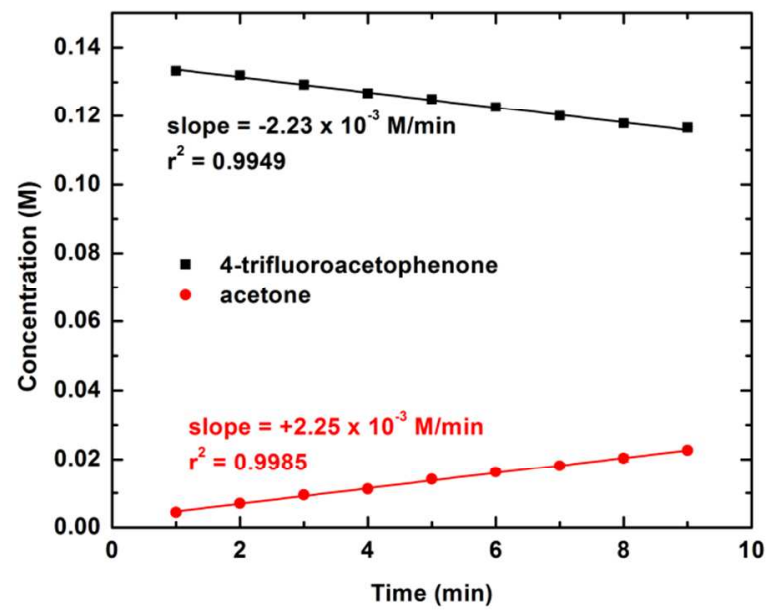

Figure S1. Kinetic data during transfer hydrogenation of 4-trifluoroacetophenone catalyzed by complex 6 showing that integration of either acetone or 4-trifluoroacetophenone yields identical rate data. These data were acquired using Method B, as outlined in the Experimental Section. Conditions: Ru:KO ${ }^{t} \mathrm{Bu}: 4-$ trifluoromethylacetophenone $=1: 20: 200,[\mathrm{Ru}]=0.5 \mathrm{mM},\left[{ }^{i} \mathrm{PrOH}\right]=12.8 \mathrm{M}, \quad[4-$ trifluoromethylacetophenone $]_{0}=0.1 \mathrm{M}, 80^{\circ} \mathrm{C}$.

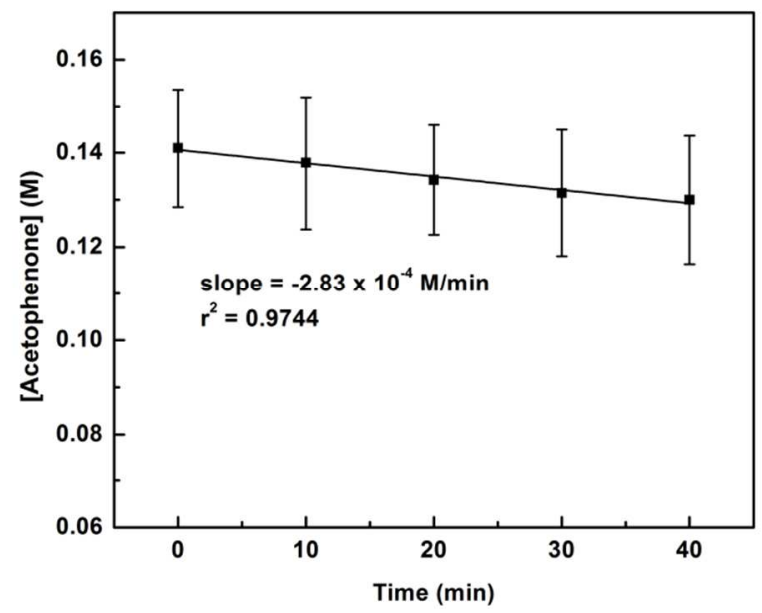

Figure S2. Representative kinetic data during transfer hydrogenation of acetophenone catalyzed by complex 6 acquired using Method $A$, as outlined in the Experimental Section. Conditions: Ru: $\mathrm{KO}^{t} \mathrm{Bu}:$ ketone $\left.=1: 20: 200,[\mathrm{Ru}]=0.5 \mathrm{mM},{ }^{i} \mathrm{PrOH}\right]_{0}=12.4 \mathrm{M}$, [acetophenone $]_{\circ}=0.1 \mathrm{M}$, [acetone $]_{\circ}=$ $0.5 \mathrm{M}, 80^{\circ} \mathrm{C}$. 


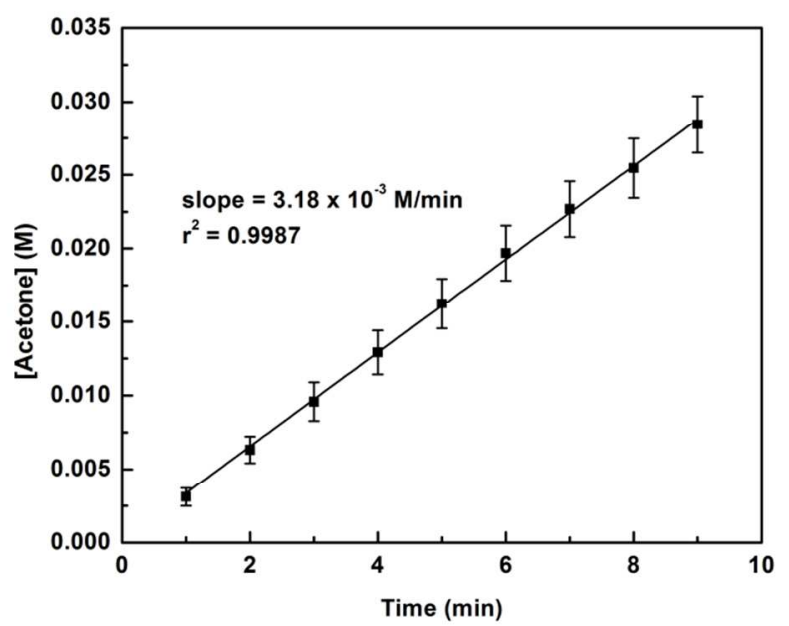

Figure S3. Representative kinetic data during transfer hydrogenation of acetophenone catalyzed by complex 6 acquired using Method B, as outlined in the Experimental Section. Conditions: Ru:Verkade's base: $\mathrm{KB}\left(\mathrm{C}_{6} \mathrm{~F}_{5}\right)_{4}$ :acetophenone $\left.=1: 20: 20: 200,[\mathrm{Ru}]=0.5 \mathrm{mM},{ }^{\prime} \mathrm{PrOH}\right]=12.8 \mathrm{M}$, [acetophenone $]_{0}=0.1 \mathrm{M}$, $80^{\circ} \mathrm{C}$.

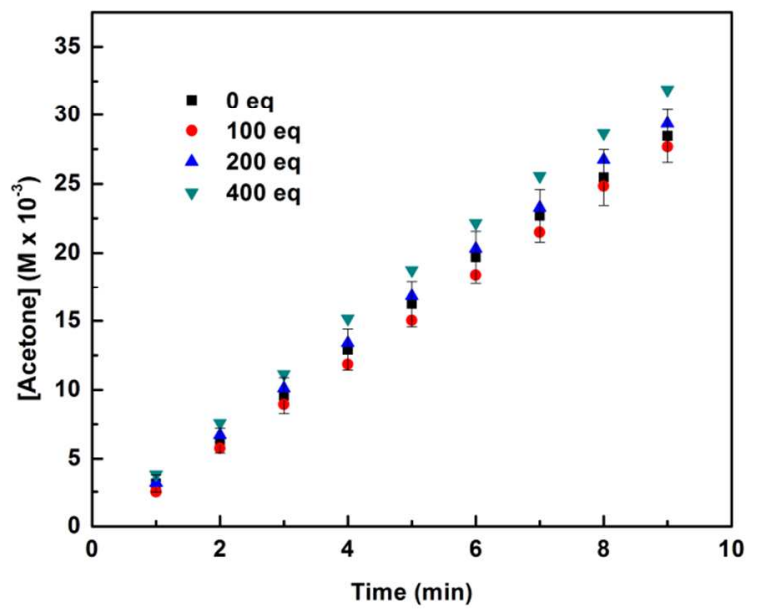

Figure S4. Effect of added ${ }^{t} \mathrm{BuOH}$ on transfer hydrogenation of acetophenone catalyzed by complex 6 , acquired using Method $B$, as outlined in the Experimental Section (equivalents of ${ }^{t} \mathrm{BuOH}$ are with respect to complex 6). Conditions: Ru:Verkade's base: $\mathrm{KB}\left(\mathrm{C}_{6} \mathrm{~F}_{5}\right)_{4}$ :acetophenone $=1: 20: 20: 200,[\mathrm{Ru}]=0.5 \mathrm{mM}$, $\left[{ }^{i} \mathrm{PrOH}\right]=12.8 \mathrm{M}$, [acetophenone $]_{o}=0.1 \mathrm{M}, 80^{\circ} \mathrm{C}$. 


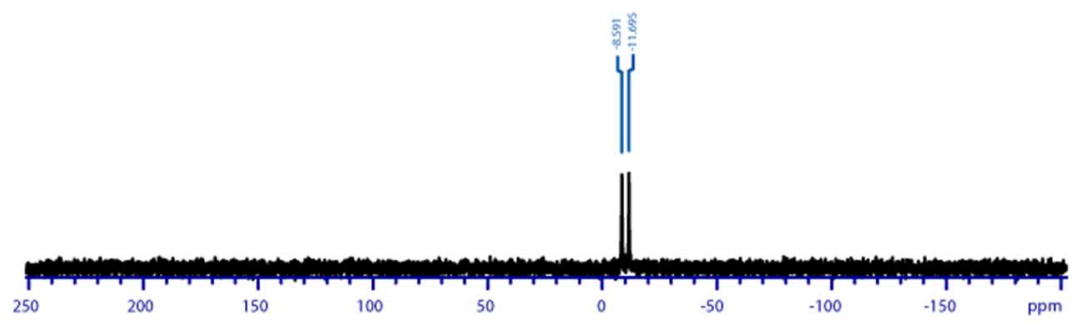

Figure S5. $162 \mathrm{MHz}{ }^{31} \mathrm{P}$ NMR spectrum of Verkade's base in 'PrOH showing complete formation of the phosphonium $\left(\mathrm{R}_{3} \mathrm{PH}^{+}\right)$ion in solution.

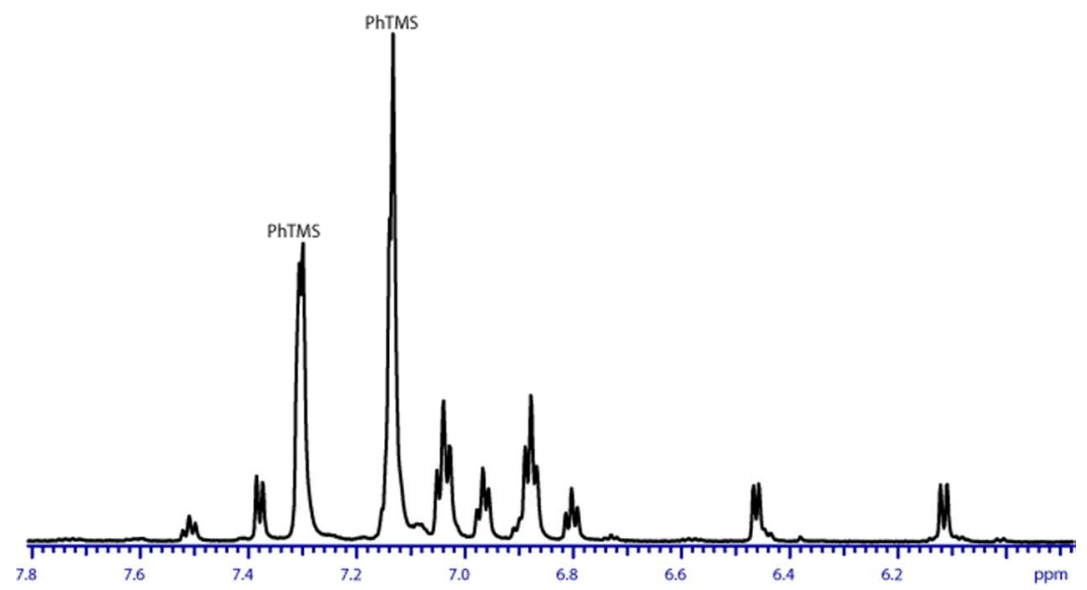

Figure S6. Aromatic region of the $700 \mathrm{MHz}{ }^{1} \mathrm{H}$ NMR spectrum of the hydride species 6-h in ${ }^{i} \mathrm{PrOH}$.

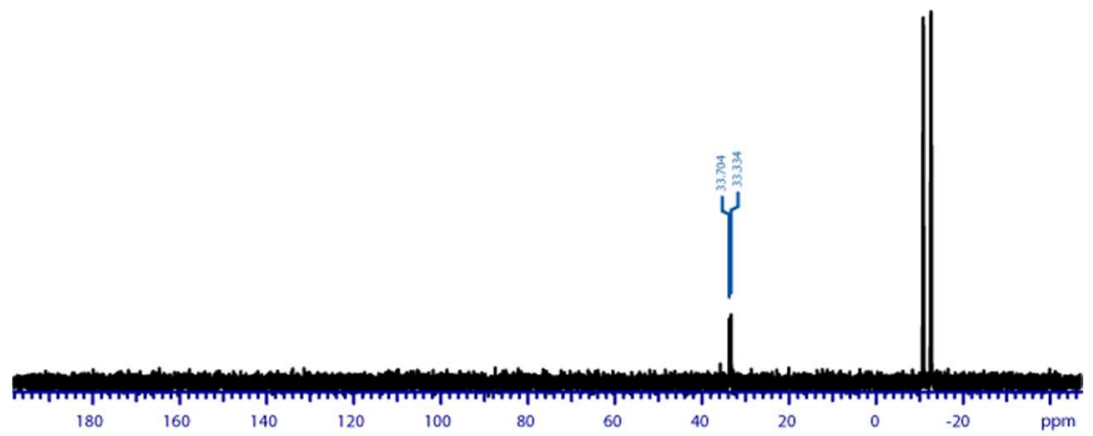

Figure S7. $283 \mathrm{MHz}{ }^{31} \mathrm{P}$ NMR spectrum of the hydride species 6-h in ${ }^{i} \mathrm{PrOH}$, along with protonated Verkade's base. 


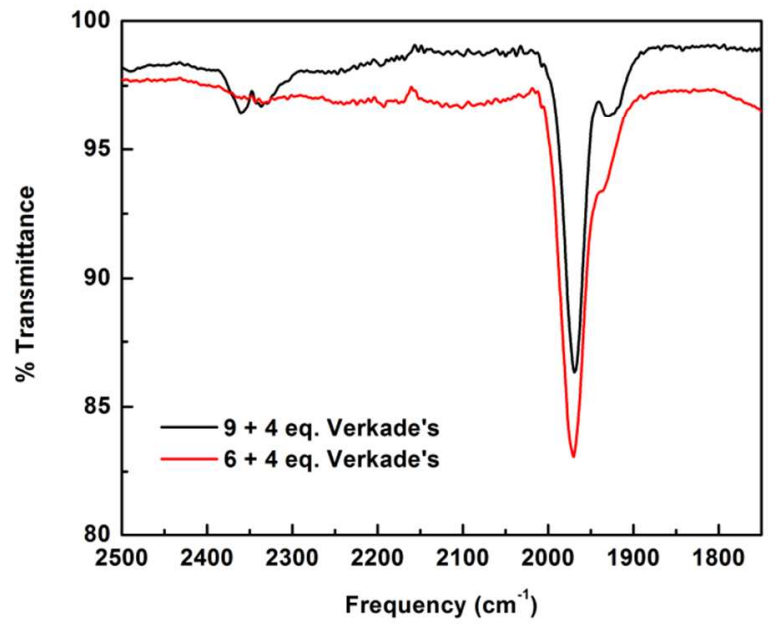

Figure S8. Overlay of ATR-IR spectra of methanol solutions of complexes 6 (red, $1969 \mathrm{~cm}^{-1}$ ) and 9 (black, $1970 \mathrm{~cm}^{-1}$ ) in the presence of 4 equivalents of Verkade's base.

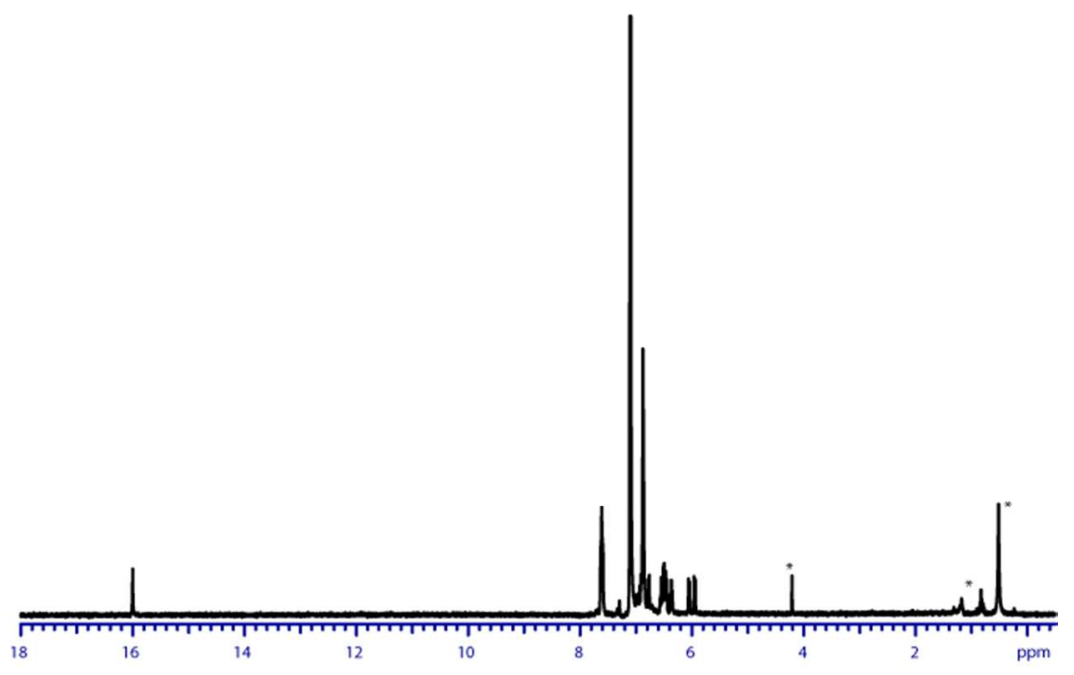

Figure S9. $400 \mathrm{MHz}{ }^{1} \mathrm{H}$ NMR spectrum of complex 1-d in $\mathrm{C}_{6} \mathrm{D}_{6}$. ${ }^{*}$ Denotes impurity $\mathrm{CH}_{2} \mathrm{Cl}_{2}$, hexane, and $\mathrm{H}_{2} \mathrm{O}$.

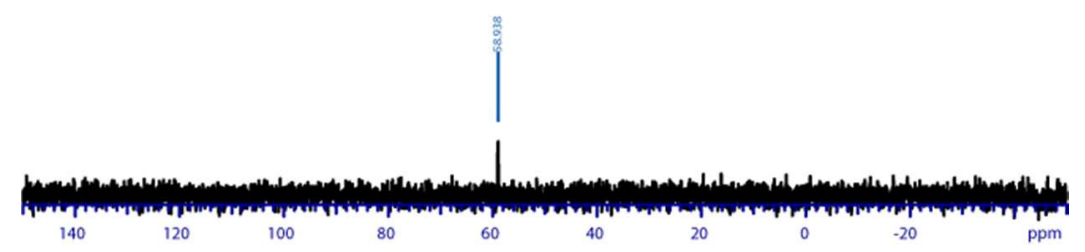

Figure S10. $162 \mathrm{MHz}{ }^{31} \mathrm{P}$ NMR spectrum of complex 1-d in $\mathrm{C}_{6} \mathrm{D}_{6}$. 


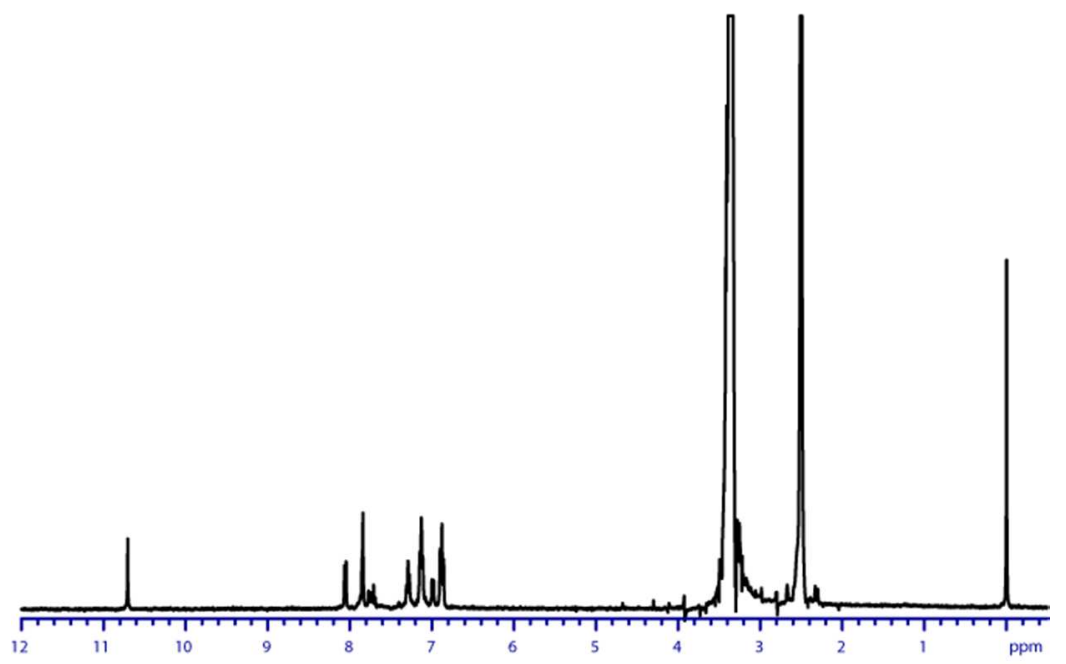

Figure S11. $400 \mathrm{MHz}{ }^{1} \mathrm{H}$ NMR spectrum of complex 2 in dmso- $d_{6}$. Note that this complex has limited solubility in common organic solvents.

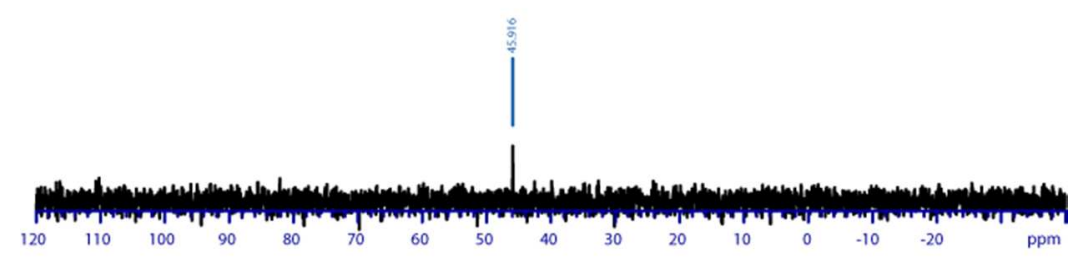

Figure S12. $162 \mathrm{MHz}{ }^{31} \mathrm{P}$ NMR spectrum of complex 2 in dmso- $d_{6}$. Note that this complex has limited solubility in common organic solvents.

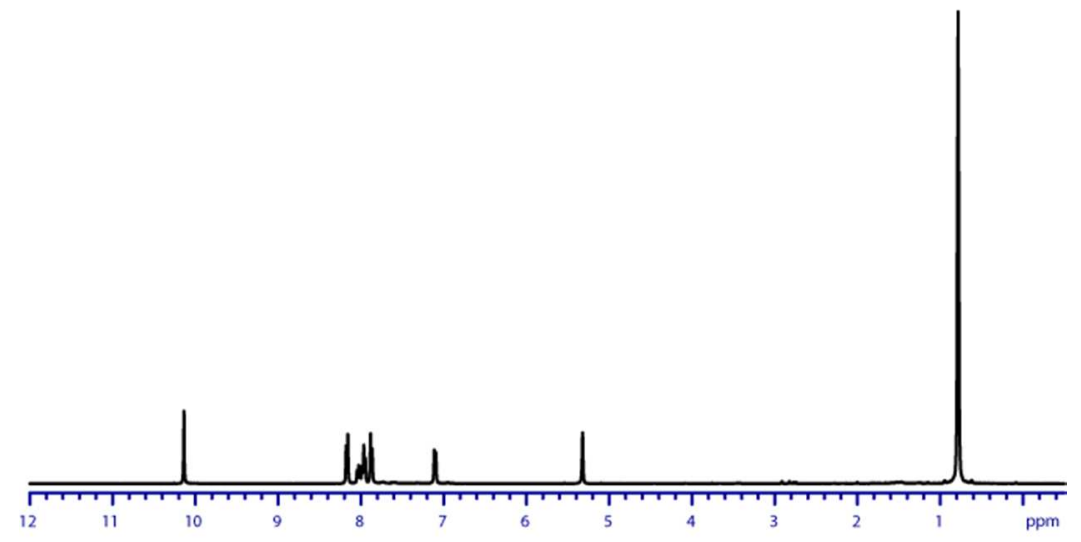

Figure S13. $400 \mathrm{MHz}{ }^{1} \mathrm{H}$ NMR spectrum of complex 3 in $\mathrm{CD}_{2} \mathrm{Cl}_{2}$. 


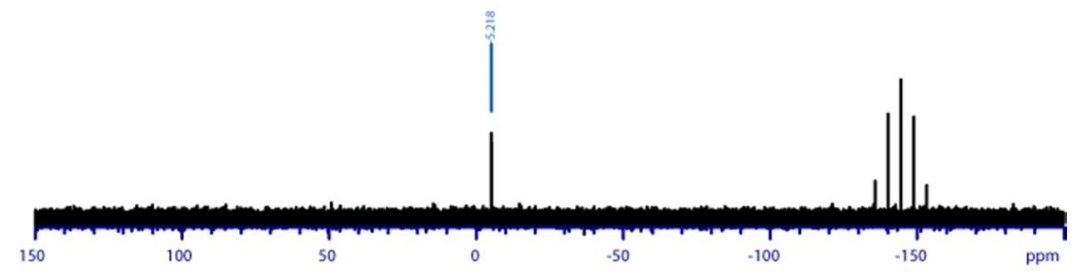

Figure S14. $162 \mathrm{MHz}{ }^{31} \mathrm{P}$ NMR spectrum of complex 3 in $\mathrm{CD}_{2} \mathrm{Cl}_{2}$.

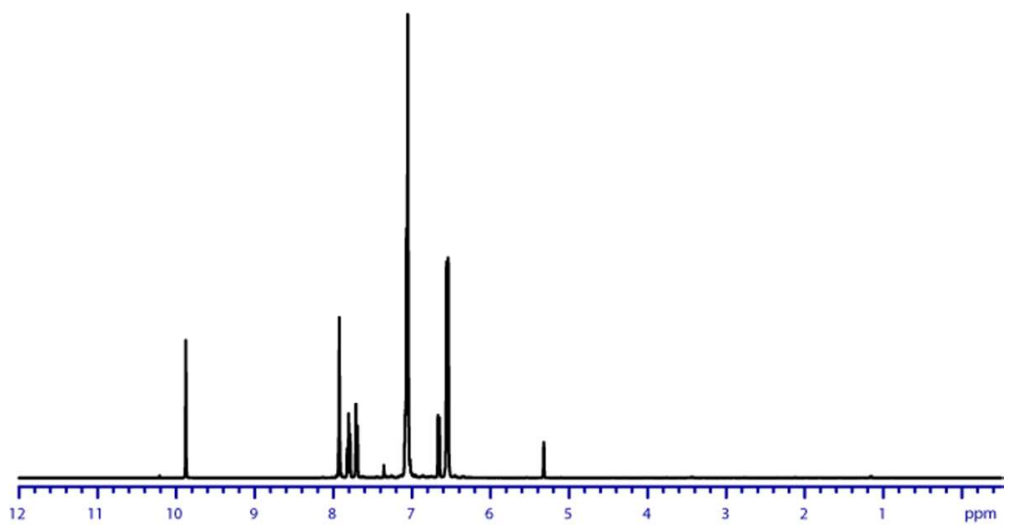

Figure S15. $400 \mathrm{MHz}{ }^{1} \mathrm{H}$ NMR spectrum of complex 4 in $\mathrm{CD}_{2} \mathrm{Cl}_{2}$.

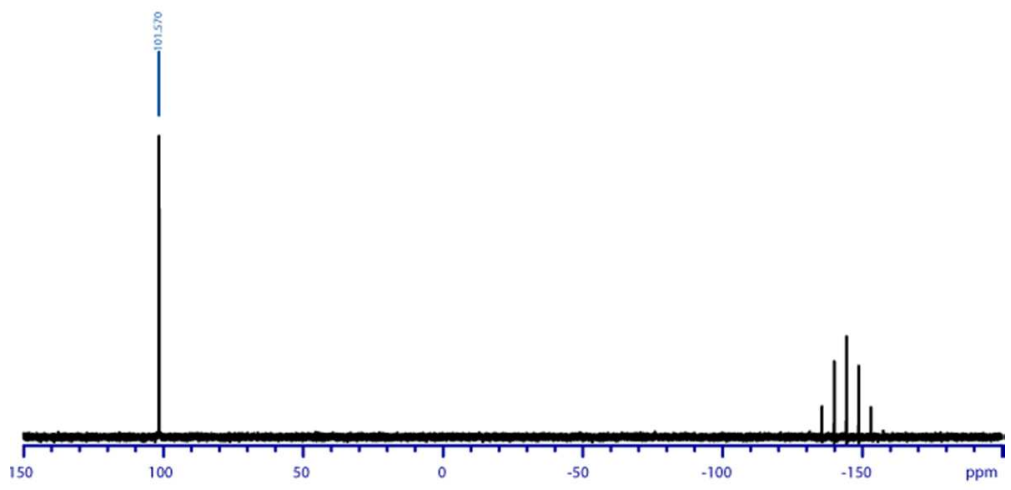

Figure S16. $162 \mathrm{MHz}{ }^{31} \mathrm{P}$ NMR spectrum of complex 4 in $\mathrm{CD}_{2} \mathrm{Cl}_{2}$. 


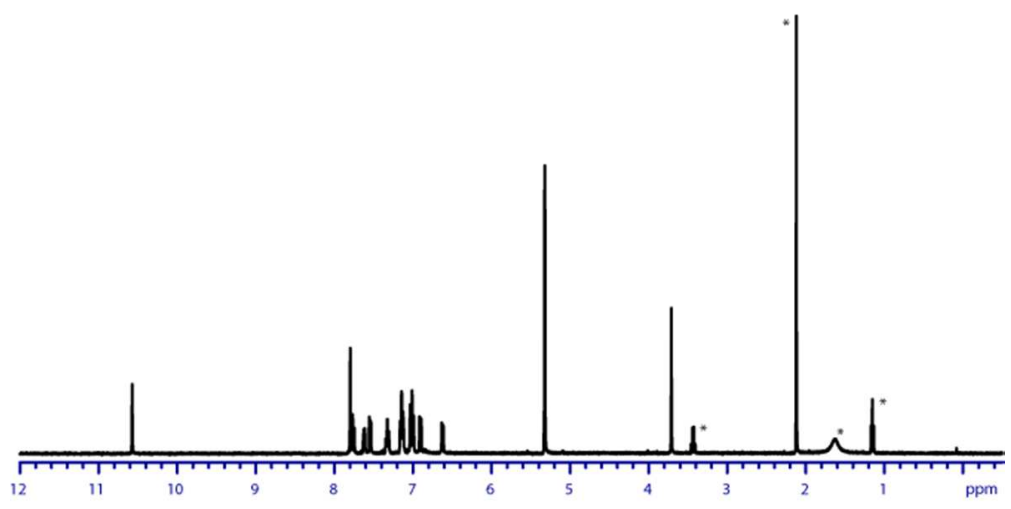

Figure S17. $400 \mathrm{MHz}{ }^{1} \mathrm{H}$ NMR spectrum of complex $\mathbf{5}$ in $\mathrm{CD}_{2} \mathrm{Cl}_{2}$. ${ }^{*}$ Denotes impurity $\mathrm{Et}_{2} \mathrm{O}$, acetone and $\mathrm{H}_{2} \mathrm{O}$.

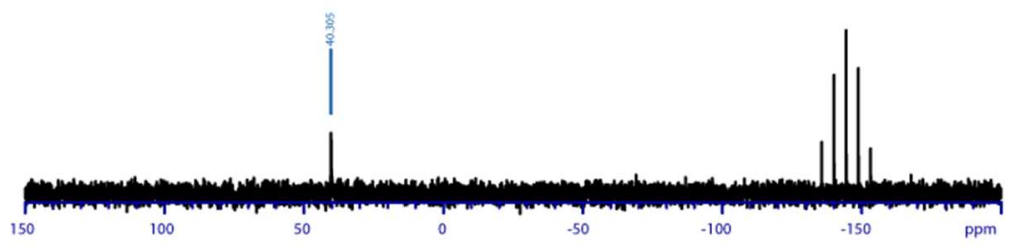

Figure S18. $162 \mathrm{MHz}{ }^{31} \mathrm{P}$ NMR spectrum of complex 5 in $\mathrm{CD}_{2} \mathrm{Cl}_{2}$.

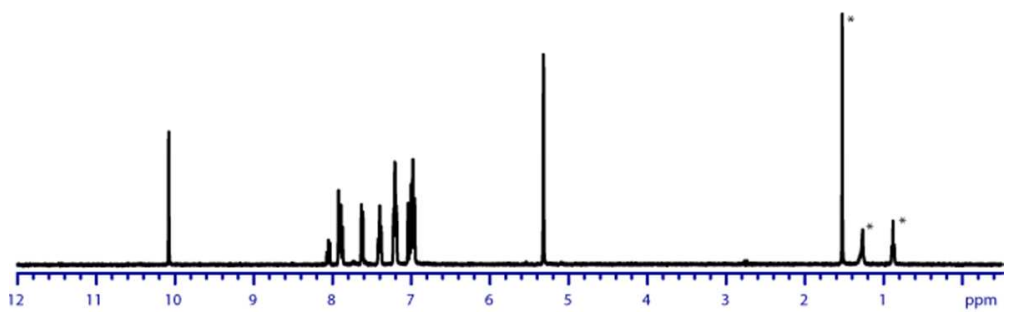

Figure S19. $400 \mathrm{MHz}{ }^{1} \mathrm{H}$ NMR spectrum of complex 6 in $\mathrm{CD}_{2} \mathrm{Cl}_{2}$. ${ }^{*}$ Denotes impurity hexane and $\mathrm{H}_{2} \mathrm{O}$.

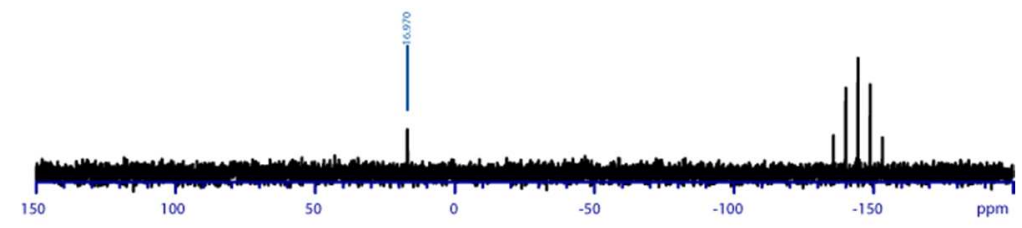

Figure S20. $162 \mathrm{MHz}{ }^{31} \mathrm{P}$ NMR spectrum of complex 6 in $\mathrm{CD}_{2} \mathrm{Cl}_{2}$. 


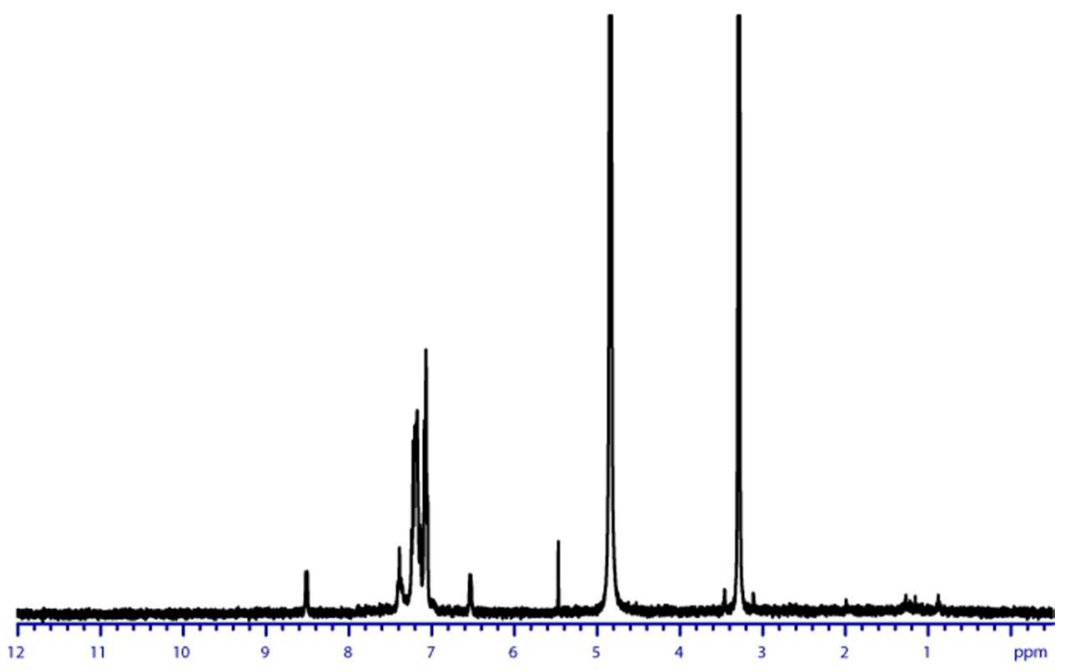

Figure S21. $400 \mathrm{MHz}{ }^{1} \mathrm{H}$ NMR spectrum of complex 8 in $\mathrm{CD}_{3} \mathrm{OD}$. Note that this complex has limited solubility in common organic solvents.

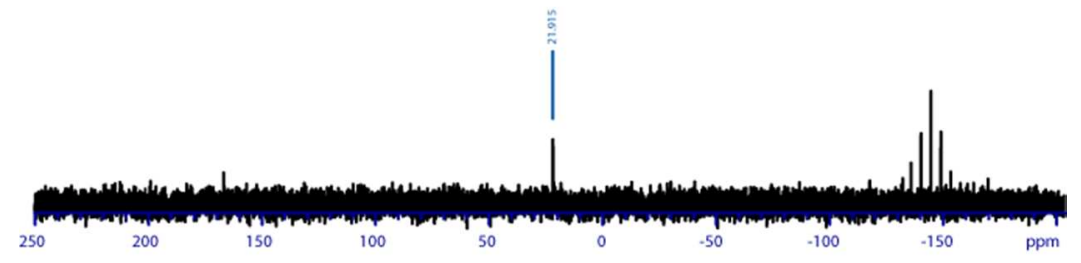

Figure S22. $162 \mathrm{MHz}{ }^{31} \mathrm{P}$ NMR spectrum of complex 8 in $\mathrm{CD}_{3} \mathrm{OD}$. Note that this complex has limited solubility in common organic solvents.

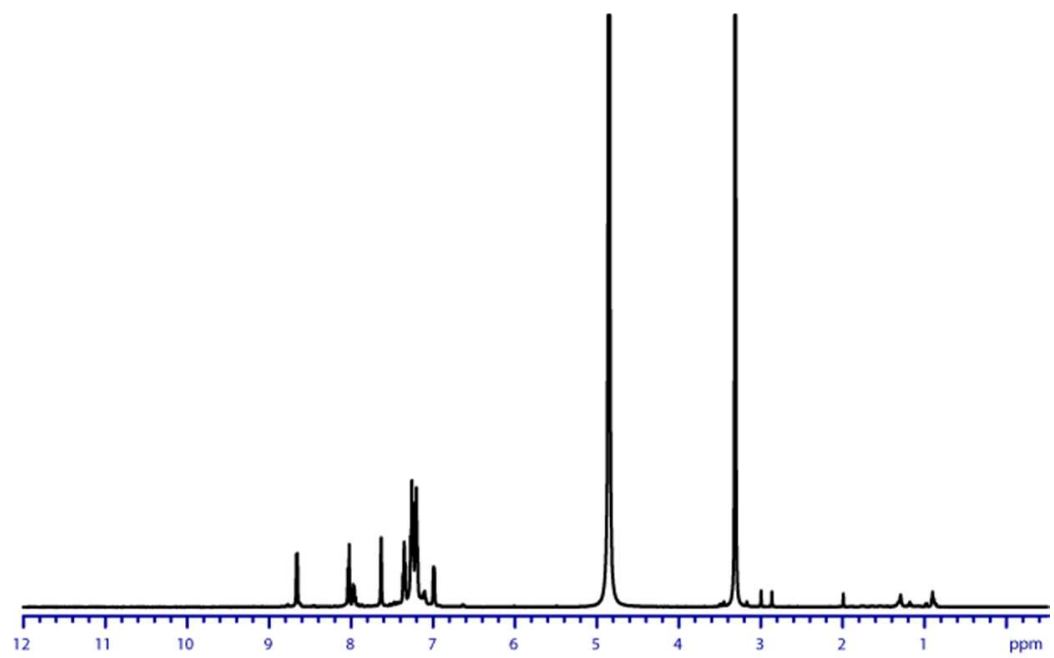

Figure S23. $500 \mathrm{MHz}{ }^{1} \mathrm{H}$ NMR spectrum of complex 9 in $\mathrm{CD}_{3} \mathrm{OD}$. Note that this complex has limited solubility in common organic solvents. 


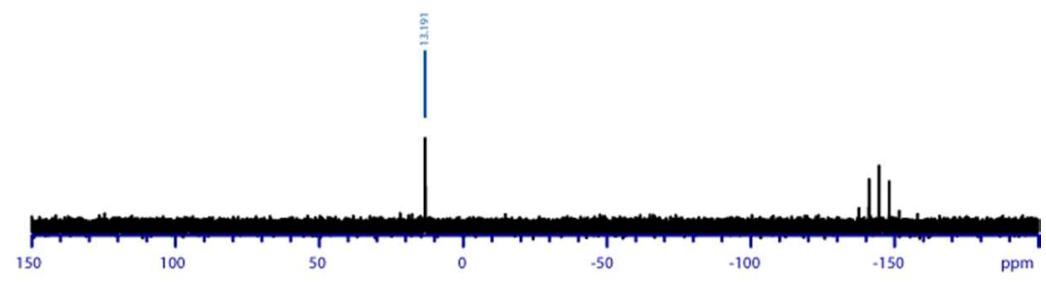

Figure S24. $202 \mathrm{MHz}{ }^{1} \mathrm{H}$ NMR spectrum of complex 9 in $\mathrm{CD}_{3} \mathrm{OD}$. Note that this complex has limited solubility in common organic solvents.

\section{References}

1. Moore, C. M.; Szymczak, N. K. Chem. Commun. 2013, 49, 400

2. Hallman, P. S.; Stephenson, T. A.; Wilkinson, G. Inorg. Syn. 1970, 12, 237.

3. Sullivan, B. P.; Calvert, J. M.; Meyer, T. J. Inorg. Chem. 1980, 19, 1404.

4. Ooyama, D.; Saito, M. Inorg. Chim. Acta 2006, 359, 800.

5. Yamamoto, Y.; Yanagi, A. Chem. Pharm. Bull. 1982, 30, 1731.

6. Korshin, E. E.; Leitus, G.; Shimon, L. J. W.; Konstantinovski, L.; Milstein, D. Inorg. Chem. 2008, 47, 7177.

7. Harzmann, G. D.; Neuburger, M.; Mayor, M. Eur. J. Inorg. Chem. 2013, 2013, 3334.

8. CrystalClear Expert 2.0 r12, Rigaku Americas and Rigaku Corporation (2011), Rigaku Americas, 9009, TX, USA 77381-5209, Rigaku Tokyo, 196-8666, Japan.

9. Sheldrick, G. Acta Cryst. A 2008, 64, 112. 